\title{
A Review of Metal Levels in Urban Dust, Their Methods of Determination, and Risk Assessment
}

\author{
Chikumbusko Chiziwa Kaonga ${ }^{1, *}$, Ishmael Bobby Mphangwe Kosamu ${ }^{1}$ (D) and Wells Robert Utembe ${ }^{2,3}(\mathbb{D}$ \\ 1 Physics and Biochemical Sciences Department, University of Malawi, The Polytechnic, Private Bag 303, \\ Chichiri, Blantyre 3, Malawi; ikosamu@poly.ac.mw \\ 2 Toxicology and Biochemistry Department, National Institute for Occupational Health (A Division of the \\ National Health Laboratory Service), Johannesburg 2000, South Africa; wutembe@cartafrica.org \\ 3 Department of Environmental Health, University of Johannesburg, Johannesburg 2000, South Africa \\ * Correspondence: ckaonga@poly.ac.mw
}

check for updates

Citation: Kaonga, C.C.; Kosamu, I.B.M.; Utembe, W.R. A Review of Metal Levels in Urban Dust, Their Methods of Determination, and Risk Assessment. Atmosphere 2021, 12, 891. https://doi.org/10.3390/atmos 12070891

Academic Editor: Polina Maciejczyk

Received: 29 April 2021

Accepted: 3 July 2021

Published: 8 July 2021

Publisher's Note: MDPI stays neutral with regard to jurisdictional claims in published maps and institutional affiliations.

Copyright: (c) 2021 by the authors. Licensee MDPI, Basel, Switzerland. This article is an open access article distributed under the terms and conditions of the Creative Commons Attribution (CC BY) license (https:/ / creativecommons.org/licenses/by/ $4.0 /)$.

\begin{abstract}
This review gives insights into the levels of metals in urban dust, their determination methods, and risk assessment. Urban dust harbors a number of pollutants, including heavy metals. There are various methods used for the sampling of urban dust for heavy-metal analysis and sourceapportionment purposes, with the predominant one being the use of plastic sampling materials to avoid prior contamination. There are also various methods for the determination of metals, which include: atomic absorption spectroscopy (AAS) and inductively coupled plasma-mass spectrometry (ICP-MS), among others. Studies have shown that pollutants in urban dust are mainly derived from industrial activities and coal combustion, whereas traffic emissions are also an important, but not a predominant source of pollution. The varying particle-size distribution of urban dust and its large surface area makes it easier for the deposition and transport of heavy metals. Risk-assessment studies have shown that metals in urban dust could cause such problems as human pulmonary toxicity and reduction of invertebrate populations. The risk levels seem to be higher in children than adults, as some studies have shown. It is therefore important that studies on metals in urban dust should always incorporate risk assessment as one of the main issues.
\end{abstract}

Keywords: heavy metals; pollution; urban dust; risk assessment; toxicity; human health

\section{Introduction}

The urban atmosphere is a recipient of various hazardous contaminants from both stationary sources, such as industries, thermal power stations, waste incinerators, and mobile sources, such as motor vehicles. Furthermore, many cities are recipients of frequent dust storms from long distances [1], such as dust particles from the Sahara desert, which, under certain weather conditions, are transported across the Mediterranean Sea to some cities in Europe [2]. By definition, dusts are solid particles, ranging in size from below $1 \mu \mathrm{m}$ up to at least $100 \mu \mathrm{m}$, which may be or become airborne, depending on their origin, physical characteristics, and ambient conditions [3]. Urban dust is often contaminated with hazardous substances, which following dermal contact, inhalation, or ingestion can cause cancer and non-cancer-related adverse effects in humans and other organisms. Heavy-metal levels in urban dust and soils are an important indicator of environmental contamination [4].

It is particularly important to study human exposure to urban dust because modern urban areas are often densely populated due to the presence of industrial and commercial activities as well as easy access to amenities such as transportation, electricity, water, entertainment, and healthcare. This results in intense resource consumption and generation of waste that may result in emission of hazardous atmospheric dust [5].

The atmospheric concentration and toxicity of urban dust depends on its location, nature of sources, proximity to sources, physico-chemical composition, and season. Ur- 
ban dust contains about two to three times the hazardous metal concentration found in urban soils [6].

In China, heavy-metal $(\mathrm{Cu}, \mathrm{Pb}$, and $\mathrm{Zn})$ levels were greater in cities located in the south than in the north [7]. Furthermore, dust from commercial and residential areas accumulated more $\mathrm{Cd}$ than dust from industrial and traffic areas, while dust from industrial areas and residential areas accumulated more $\mathrm{Pb}$ than dust from commercial and traffic areas. $\mathrm{A}$ comparison of 2007 and 2012 contamination levels also indicated temporal changes, with lower Cd concentrations in 2012 than in 2007; this change could be attributed to relocation of many industries from the Beijing region [8]. These and other studies have shown the impact of sources and proximity of receptors to sources on the concentration and composition of atmospheric dust.

Since there are seasonal changes in climatic conditions such as temperature, rainfall, and humidity, as well as changes in the types and intensities of human activity, many studies have reported seasonal differences in atmospheric particulate matter (PM) and heavy-metal concentrations in PM $[5,9,10]$. Temporal variations, such as seasonal, weekday/weekend, and diurnal/nocturnal fluctuations, may provide additional information on the sources of PM [11]. Moreover, various methods exist for source apportionment of atmospheric dust. All these approaches can have an impact on the results of health-risk assessment that are conducted in various urban areas to evaluate the potential adverse health impacts of atmospheric dust on humans and other species.

Indeed, health-risk assessment of heavy metals in urban dust has been conducted in various countries including, inter alia, Iran [12,13], China [14-16], Nepal [4], Armenia [17], Malaysia [18], and Pakistan [19]. These studies have shown different levels of heavy metals in urban atmospheric environments, as well as different levels of risk, through inhalational exposure, ingestion, and/or dermal contact. Furthermore, the assessment of heavy metals and the subsequent risk assessments were conducted using different approaches. Therefore, this paper presents a review of the literature on heavy metals in urban atmospheric dust, focusing on key findings, common areas and gaps in studies, the methods used for sampling, analysis of dust, source apportionment, and health-risk assessment.

\section{Sampling Methods for Urban Dust}

There are various methods of sampling urban dust. Those that have been reported include the use of: a plastic dustpan and a brush [14,20-22], a plastic hand broom and dustpan [23,24], brushing $1 \mathrm{~m}^{2}$ of previously delimited surface of asphalt [25], an ABA1-120-02A portable aspirator [17,26], a brush and plastic hand shovel [27], a vacuum cleaner $[8,28]$, and a portable high-pressure washer device with a piston fitted into a rigid, sealed rubber dome [29].

These methods are used mainly for dry dust samples. According to Lundberg et al. [30], in snowy and wet conditions, a wet dust sampler (WDS) becomes handy. The wet dust sampler uses a principle of flushing high-pressurised water over a defined surface area and transferring the dust-laden water into a container for further analyses.

Apart from these methods that are used for the actual sampling of the dust for heavy-metal analysis, Colinet [31] describes some dust-sampling instruments that contain detectors that give the real-time concentration of dust in a specific area. These include a gravimetric dust sampler that provides time-weighted-average respirable dust concentration, and a personal dust monitor (PDM) that provides instant measurement of respirable dust. Combining these methods of dust sampling with the results of heavy-metal analysis gives an idea of the potential risk of urban dust to human health.

\section{Determination Methods for Heavy Metals in Urban Dust}

The determination of heavy metals in urban dust has been done using different methods across the globe. The commonly used methods are summarised in Table 1. 
Table 1. A summary of the dust measurement methods.

\begin{tabular}{cc}
\hline Method Used for Measuring Dust & References \\
\hline $\begin{array}{c}\text { Atomic Absorption Spectrophotometry (AAS) and Atomic Fluorescence } \\
\text { Spectrophotometry (AFS) }\end{array}$ & {$[32,33]$} \\
\hline $\begin{array}{c}\text { Spectrometry (ICP-DRC-MS). } \\
\text { Inductively Coupled Plasma-Dynamic Reaction Cell-Mass }\end{array}$ & {$[28]$} \\
\hline Inductively Coupled Plasma Mass Spectrometry (ICP-MS) & {$[20,23,24,34]$} \\
\hline Atomic Absorption Spectrophotometry (AAS) & {$[5,17,26,27,35]$} \\
\hline $\begin{array}{c}\text { Inductively Coupled Plasma-Optical Emission Spectroscopy (ICP-OES) } \\
\text { and Cold Vapor Generation-Atomic Fluorescence Spectrometry } \\
\text { (CV-AFS, XGF-1011A) }\end{array}$ & {$[8,14,22]$} \\
\hline X-ray Spectrometry for Energy-Dispersive Spectroscopy (EDS) & {$[36]$} \\
\hline Energy-Dispersive X-ray Fluorescence Spectroscopy & {$[21,37]$} \\
\hline Flame Atomic Absorption Spectroscopy (FAAS) & {$[38]$} \\
\hline Energy-Dispersive & \\
\hline
\end{tabular}

According to Bioline [39], the following factors should be considered when purchasing equipment for analysis of samples in the laboratory: price, service contract (warranty), availability of spare parts and consumables, technical support and system updates, and end-user ability to operate the equipment. There are also other factors such as time taken by the instrument to complete analysis, accuracy, and precision.

According to Brooks Applied Labs [40], due to its ion beam smoothing technology, the ICP-DRC-MS has been seen to support a much more static ion beam, leading to less variability in replicate measurements. The ICP-DRC-MS also has another advantage, which is that elements with a high first ionization potential can be determined with no loss of sensitivity [41]. The disadvantages of ICP-DRC-MS are the high initial capital costs and the exorbitant operational costs. According to Wilschefski and Baxter [42], the ICP-MS has the following as advantages: multi-element technique, large analytical range, low detection limit, low sample volume, and a very high level of interference control. It has the following disadvantages: high equipment and operating costs, and it requires a high level of staff expertise and that interferences be controlled. ICP-AES (also known as ICP-OES) has the following advantages: multi-element technique, large analytical range, low sample volume, and simple sample preparation. The following are the disadvantages of ICP-AES: high detection limit, high equipment cost, and high level of human-resource expertise. Flame atomic emission has the following advantages: reasonable equipment cost, low level of staff expertise, simple sample preparation, and low laboratory setup cost. The following are the disadvantages of flame atomic emission: single-element technique, limited analytical range, high detection limit, higher sample volume, and use of flammable gases. Flame atomic absorption has the following advantages: reasonable equipment cost, low level of staff expertise, simple sample preparation, reasonably high sample throughput, and few interferences. The following are disadvantages of flame atomic absorption: singleelement technique, limited analytical range, high detection limit, higher sample volume, and use of flammable gases. Atomic absorption (cold vapour/hydride generation) has the following advantages: low detection limit, reasonable equipment cost, few interferences, and low laboratory setup cost. The following are disadvantages of atomic absorption (cold vapour/hydride generation): suitable for limited elements, limited analytical range, low sample throughput, high sample volume, and complex acid digestions are required for biological samples.

Mathias [43] gave the following as advantages of X-ray spectrometry: analysis is effective across a range of organic and inorganic materials, analyses stainless steel passivation, effective at identifying surface contaminants, and is an efficient testing method in that 
an analysis can be done within $30 \mathrm{~min}$. The disadvantages are that sample size matters, there are challenges with reproducibility, and samples must be compatible with a high vacuum environment.

\section{Source Apportionment of Heavy Metals in Urban Dust}

The heavy metals in dust from various sources have been shown to have different bioavailabilities that result in different health-risk levels [44]. Therefore, the determination of different constituents of urban dust and their levels together with their sources is important for their risk assessment and management [45]. Quantification of health risks according to sources, rather than individual pollutants, may reveal complex pollutant interactions that reflect the relationships between urban dust and adverse human health [46].

The most common approaches used in source apportionment of urban dust include receptor models and isotopic analysis. Receptor models include chemical mass balance (CMB) analyses, enrichment factor (EF) analysis and statistical multivariate factor analysis such as positive matrix factorization (PMF), principal component analysis (PCA), clustering analysis (hierarchical cluster analysis), and multivariate curve resolution [47]. Receptor models require the analysis of physico-chemical properties of dust measured at one or more specific receptor sites [48], as well as the use of databases that contain chemical analyses information for both major and trace chemical compounds from various emission sources [47].

Chemical mass balance (CMB) approaches are widely applied for source apportionment to estimate contributions from all independent sources using mass-balance equations that account for all chemical species in the available number of samples [49]. CMB analyses use physico-chemical characteristics of particles measured at various sources and receptors to estimate contributions of each source to the receptor [46]. CMB approaches calculate a solution to a set of linear equations that express ambient chemical concentrations at each receptor as a linear sum of products of source-profile abundances and source contributions [50]. The main assumption in CMB approaches is that chemical profiles at the source do not change as the pollutants are transported from the source and to the receptor. This assumption may not be valid at all times. Enrichment factor $(E F)$ analysis has been used to study sources of pollutants by discriminating anthropogenic sources from natural sources in sample matrices such as soils and urban dust [51]. This approach compares the relative concentration of an analyte accumulated in dust to that in background:

$$
E F=\frac{\left(\frac{C_{x}}{C_{\text {Ref }}}\right)_{\text {sample }}}{\left(\frac{C_{X}}{C_{\text {Ref }}}\right)_{\text {background }}}
$$

where $C_{x}$ is the concentration of target metal and $C_{\text {Ref }}$ is the concentration of the reference element [52]. A reference element is characterized by large stability in the soil and absence of vertical mobility and/or degradation [53]. An EF close to 1 indicates that the element did originate from the soil [54], while $E F$ values greater than 1 typically indicate that the sample is enriched from anthropogenic sources [51]. Due to limited capabilities to discriminate among multiple sources, $E F$ analysis does not identify sources in complex source setups. Statistical multivariate approaches such as PCA are better at distinguishing multiple sources. Nevertheless, statistical approaches just provide general information about sources.

The multivariate methods provide information about association among pollutants and their sources in a manner that is not possible with conventional descriptive statistical analyses. Correlation analysis can be used to investigate chemical-environmental associations among heavy metals that can reflect possible relationships among their sources, while PCA can unravel existing relationships between environmental (meteorological) factors and concentrations of heavy metals [55]. Cluster analysis (CA), which aggregates data 
according to the similarity of their features, simplifies and classifies the characteristics and properties of environmental pollutants in a specific region [56].

Isotopic analyses are based on ratios of some stable isotopes such as carbon, oxygen, and lead to provide sources of urban dust. Isotopic analysis provides more specific and accurate approaches for identification of sources in urban dust [8]. Lead isotopes have been the most widely used in the source apportionment of heavy metals. Natural lead comprises four stable isotopes- $\mathrm{Pb}-204, \mathrm{~Pb}-206, \mathrm{~Pb}-207$, and $\mathrm{Pb}-208$ - in ratios that vary over time due to the radioactive decay of $238 \mathrm{U}(206 \mathrm{~Pb}), 235 \mathrm{U}(207 \mathrm{~Pb})$, and $232 \mathrm{Th}(208 \mathrm{~Pb})$. Since anthropogenic lead has different isotopic ratios from geogenic sources such as soil, $\mathrm{Pb}$-bearing media can reliably be distinguished from each other [57]. Other heavy metals used in isotopic analysis include, among others, $\mathrm{Cd}$ [58], $\mathrm{Hg}$ [59], Cu, and $\mathrm{Zn} \mathrm{[60].}$

Generally, source apportionment is important for the prevention of heavy metals in urban dust. However, source-apportionment methods are deficient or inadequate when applied exclusively. In this regard, the integrated use of suites of complementary source-apportionment tools can eliminate their individual deficiencies and provide a more accurate approach for identification of sources of urban dust. For example, [51] used PEF analysis to confirm the anthropogenic origin of $\mathrm{Na}, \mathrm{Cu}, \mathrm{Cd}, \mathrm{Zn}, \mathrm{Sn}, \mathrm{K}, \mathrm{Ca}, \mathrm{Sb}, \mathrm{Ba}, \mathrm{Ti}$, $\mathrm{Ni}$, and Mo. Among these sources, hierarchical cluster analysis (HCA) and PCA could identify four sources, including soil, asphalt wear, tyre wear, and brake wear. Similarly, Huang et al. [59] used isotopic analysis, GIS mapping, and multivariate statistical analysis for source apportionment in peri-urban agricultural soils: GIS mapping could show that $\mathrm{Cd}$ pollution originates from point sources, whereas $\mathrm{Hg}$, $\mathrm{Pb}$, and $\mathrm{Cr}$ were from both point and non-point sources. Principal component analysis (PCA) indicated that $\mathrm{Mn}$ and Ni were from natural sources, while $\mathrm{Hg}, \mathrm{Pb}$, and $\mathrm{Cd}$ were from two different anthropogenic sources, which CA identified as wastewater, industrial solid wastes, road dust, fertilizers, and atmospheric deposition.

Zhao et al. [61] used isotopic analysis and multivariate statistical analysis for soil apportionment of heavy metals in urban road dust in China. The isotopic analysis could show that $\mathrm{Pb}$ in dust was mainly from vehicular traffic and industrial emissions (at $61 \%$ and $26 \%$ contributions, respectively), while Sr originated from anthropogenic sources and the soil (at $59.7 \%$ and $40.3 \%$ contributions, respectively). On the other hand, multivariate statistical analysis could show that the total heavy metals primarily originated from motor vehicles $(43 \%)$, industrial emissions $(29 \%)$, soil $(21 \%)$, and unknown sources $(7 \%)$. The isotopic analyses and multivariate statistical analysis were perfectly complementary.

\section{Levels of Heavy Metals in Urban Dust}

Table 2 shows levels of heavy metals in urban dust from some parts of the world. These values were comparable in most cases, but there were still some extremes. For example, a value of $141 \mathrm{mg} / \mathrm{kg}$ for Ag from Nepal [4] did not compare well with values of $5.5 \mathrm{mg} / \mathrm{kg}$ and $4.55 \mathrm{mg} / \mathrm{kg}$ from Angola [62] and Spain [63], respectively, for the same metal. This was also the case for the other metals. The main cause of these variations was the presence of such industries like mining and others near the sampling areas. 
Table 2. Heavy-metal levels in urban dust of some parts of the world.

\begin{tabular}{|c|c|c|c|}
\hline Metal & Max. Detected Conc. (mg/kg) & Country & Author \\
\hline \multirow{3}{*}{$\mathrm{Ag}$} & 141 & Nepal & [4] \\
\hline & 5.5 & Angola & [62] \\
\hline & 4.55 & Spain & [63] \\
\hline \multirow{8}{*}{$\mathrm{Cd}$} & 55.8 & Nepal & [4] \\
\hline & 11.0 & China & [7] \\
\hline & 0.85 & Iran & [13] \\
\hline & 0.352 & Poland & [36] \\
\hline & 4 & Angola & [62] \\
\hline & 104 & Spain & [63] \\
\hline & 2.54 & South Africa & [64] \\
\hline & 0.78 & India & [65] \\
\hline \multirow{5}{*}{ Co } & 46.1 & Nepal & [4] \\
\hline & 7 & Angola & [62] \\
\hline & 11.5 & Spain & [63] \\
\hline & 36.2 & South Africa & [64] \\
\hline & 16.9 & India & [65] \\
\hline \multirow{10}{*}{$\mathrm{Cr}$} & 712 & Nepal & [4] \\
\hline & 233 & China & [7] \\
\hline & 105.9 & Iran & [13] \\
\hline & 1058.7 & Mexico & [21] \\
\hline & 60.2 & Colombia & [27] \\
\hline & 211 & Poland & [36] \\
\hline & 37 & Angola & [62] \\
\hline & 54.5 & Spain & [63] \\
\hline & 221.9 & South Africa & [64] \\
\hline & 75.4 & India & [65] \\
\hline \multirow{10}{*}{$\mathrm{Cu}$} & 1250 & Nepal & [4] \\
\hline & 261 & China & [7] \\
\hline & 232.5 & Iran & [13] \\
\hline & 490.2 & Colombia & [27] \\
\hline & 176.2 & Algeria & [35] \\
\hline & 239 & Poland & [36] \\
\hline & 118 & Angola & [62] \\
\hline & 374 & Spain & [63] \\
\hline & 157.2 & South Africa & [64] \\
\hline & 56.8 & India & [65] \\
\hline
\end{tabular}


Table 2. Cont.

\begin{tabular}{|c|c|c|c|}
\hline Metal & Max. Detected Conc. (mg/kg) & Country & Author \\
\hline \multirow{8}{*}{$\mathrm{Ni}$} & 210 & Nepal & [4] \\
\hline & 129 & China & [7] \\
\hline & 117.9 & Iran & {$[13]$} \\
\hline & 75.6 & Algeria & [35] \\
\hline & 43.7 & Poland & [36] \\
\hline & 32 & Angola & [62] \\
\hline & 74.3 & South Africa & [64] \\
\hline & 66 & India & {$[65]$} \\
\hline \multirow{12}{*}{$\mathrm{Pb}$} & 1070 & Nepal & [4] \\
\hline & 375 & China & [7] \\
\hline & 234.3 & Iran & [13] \\
\hline & 1070.1 & Mexico & [21] \\
\hline & 1289.4 & Colombia & [27] \\
\hline & 993.84 & Algeria & {$[35]$} \\
\hline & 430 & Poland & [36] \\
\hline & 1856 & Angola & [62] \\
\hline & 964 & Spain & {$[63]$} \\
\hline & 304.6 & South Africa & {$[64]$} \\
\hline & 67.8 & India & [65] \\
\hline & 558 & United Kingdom & [66] \\
\hline \multirow{5}{*}{$\mathrm{Sb}$} & 17.5 & Nepal & [4] \\
\hline & 9.45 & Iran & [13] \\
\hline & 37 & Angola & {$[62]$} \\
\hline & 9.00 & Spain & {$[63]$} \\
\hline & 2.54 & South Africa & [64] \\
\hline \multirow{3}{*}{$\mathrm{Fe}$} & 1070 & Nepal & [4] \\
\hline & 50,298 & Poland & [36] \\
\hline & 20,100 & Angola & {$[62]$} \\
\hline \multirow{7}{*}{ Mn } & 3480 & Nepal & [4] \\
\hline & 652 & Iran & [13] \\
\hline & 974.4 & Algeria & [35] \\
\hline & 728 & Angola & [62] \\
\hline & 3.148 & Spain & [63] \\
\hline & 392.4 & South Africa & {$[64]$} \\
\hline & 658 & India & [65] \\
\hline
\end{tabular}


Table 2. Cont.

\begin{tabular}{|c|c|c|c|}
\hline Metal & Max. Detected Conc. (mg/kg) & Country & Author \\
\hline \multirow{11}{*}{$\mathrm{Zn}$} & 2300 & Nepal & [4] \\
\hline & 2716 & China & [7] \\
\hline & 778.3 & Iran & [13] \\
\hline & 4426.4 & Mexico & [21] \\
\hline & 387.6 & Colombia & [27] \\
\hline & 1009 & Algeria & [35] \\
\hline & 2030 & Poland & {$[36]$} \\
\hline & 1412 & Angola & [62] \\
\hline & 23,400 & Spain & [63] \\
\hline & 754.3 & South Africa & [64] \\
\hline & 163.6 & India & [65] \\
\hline \multirow{6}{*}{ As } & 13.8 & Nepal & [4] \\
\hline & 8.6 & Iran & [13] \\
\hline & 7.8 & Angola & [62] \\
\hline & 26 & Spain & [63] \\
\hline & 5.02 & South Africa & [64] \\
\hline & 4.1 & India & [65] \\
\hline \multirow{3}{*}{$\mathrm{Hg}$} & 4.504 & Iran & [13] \\
\hline & 0.57 & Angola & {$[62]$} \\
\hline & 10.8 & Spain & [63] \\
\hline
\end{tabular}

The presence of heavy metals in urban dust has been studied, and is prominently used as one of the indicators of environmental contamination across the globe $[8,12,67]$. Most of these studies have linked the presence of heavy metals in urban dust to stationary (power plants, industries, incinerators, and residential heating) and mobile sources (vehicular exhausts and abrasion of vehicle body parts such as tyres). As observed by Benhaddya et al. [35], the differentiation of dust particle sizes and their large surface area makes them an excellent mode of transport and deposition of heavy metals in the environment. Urban environments have also been subjected to impacts of dust storms, which are known to collect and deposit pollutants in cities [68,69]. A study by Zhu et al. [70] revealed that metal pollutants in the dust in urban environments were derived mainly from industrial activities and coal combustion, whereas the traffic emissions were not a predominant source of pollution.

A wide range of sizes of dust particles also was reported by Abbasi et al. [71], who used fluorescence microscopy to establish that dust particles from areas with heavy traffic circulation were finer than those from other locations. Liu et al. [72] additionally linked population density to toxic levels of heavy-metal pollution in urban dust. Since the population densities of most cities worldwide continue to increase due to urbanization, there is need to devise mechanisms that will abate the levels of these heavy metals in urban dust [72]. In the literature reviewed, it was shown that the most studied heavy metals in urban dust include $\mathrm{Hg}$, As, $\mathrm{Cd}, \mathrm{Cu}, \mathrm{Cr}, \mathrm{Ni}, \mathrm{Mn}, \mathrm{Fe}, \mathrm{Pb}, \mathrm{Sb}$, and $\mathrm{Zn}$ [35]. A study by FerreiraBaptista and De Miguel [62] found elevated levels of arsenic and lead in dust particles in the streets of Luanda in Angola, despite uncertainties regarding the sources, exposure factors, and toxicity values of the heavy metals. Similarly, Benhaddya et al. [35] found that levels and non-carcinogenic health risk from heavy metals $(\mathrm{Cu}, \mathrm{Mn}, \mathrm{Ni}, \mathrm{Pb}$, and $\mathrm{Zn})$ in urban dust from Hassi Messaoud in Algeria were extremely elevated. Olowoyo et al. [64] 
also found elevated concentrations of $\mathrm{Pb}, \mathrm{Mn}, \mathrm{Cu}, \mathrm{Zn}$, and $\mathrm{Cr}$ in urban classroom dust from selected high schools in Pretoria, South Africa. On the contrary, a study by Liu et al. [72] found that "the non-carcinogenic health risk resulting from exposure to the potentially toxic metals from urban trunk roads (TR) in Nanjing, in China, was within safe levels based on the Hazard Index (HI), except in pollution hotspots where exposure to $\mathrm{Pb}, \mathrm{Cr}$, and $\mathrm{Cu}$ may be hazardous to children". A study by Praveena [22] in Malaysia found that the highest potentially toxic element concentration in urban road dust was $\mathrm{Pb}(593.3 \mathrm{mg} / \mathrm{kg})$, whereas the lowest was Co $(5.6 \mathrm{mg} / \mathrm{kg}$ ), and a linkage to anthropogenic sources (urbanization process, industrial and commercial growth, and urban traffic congestion) was stipulated. The findings by Praveena [22] were consistent with findings by Shabanda et al. [18], who reported $\mathrm{Pb}, \mathrm{Cu}$, and $\mathrm{Zn}$ as the most representative metals in dust samples from Petaling Jaya, Malaysia.

Another study done by Sahakyan et al. [17] in Armenia established the presence of heavy metals $(\mathrm{Pb}, \mathrm{Zn}, \mathrm{Cu}, \mathrm{Cr}, \mathrm{Ni}$, and $\mathrm{Mo})$ in urban dust, and the mean concentrations of all the detected metals exceeded geochemical background levels by 1.1-5.0 times. A study of the spatial characteristics and pollution levels of metals in urban street dust of Beijing, China [73] established varied concentrations of heavy metals in the following descending order: $\mathrm{Mn}>\mathrm{Cr}>\mathrm{Cu}>\mathrm{Pb}>\mathrm{Ni}>\mathrm{Cd}$.

Elom et al. [66] found urban dust in cities in the northern part of United Kingdom to contain total lead concentrations ranging from 306 to $558 \mathrm{mg} / \mathrm{kg}$, which was above those found in other cities worldwide. Rajaram et al. [74] studied heavy-metal levels in the city of Delhi in India, and found that the levels were low and quite comparable to those in other cities in the world. A study by Amato et al. [75] that instigated heavymetal loadings in road dust (below $10 \mathrm{~mm}$ ) in the three European urban cities of Barcelona, Girona, and Zürich established that the loadings were lowest in Zürich (Switzerland), while Barcelona (Spain) recorded the highest concentration of the three cities. Davila et al. [38] found acceptable levels of heavy metals in urban dust in the city of Vigo (Ria de Vigo) in Spain, the main source of which was found to be harbor activities and vehicle emissions. These findings contrasted remarkably with the high levels of heavy metals from the city of Talcahuano in Chile, which exceeded the ecologically safe levels for avian wildlife as established by the Environmental Protection Agency [76]. However, a study of heavy metals in urban dust in the three cities of Torreon, Chihuahua, and Monterrey in northern Mexico [77] established very high levels of heavy metals (greater than EPA limits), especially in residential neighbourhoods around metal smelting and refining sites, thereby posing a health risk to the people residing there. The findings from all these studies clearly showed that heavy-metal pollution in urban environments is noticeably becoming an issue of concern and a threat to urban human population.

\section{Risk Assessment}

Risk assessment is performed to systematically evaluate the potential adverse health impacts from chemical exposures. The current risk assessment process comprises four steps that include hazard identification, dose-response assessment, exposure assessment and risk characterization. The hazard-identification step aims to determine the inherent potential of a substance to cause harm in vitro or in vivo (in animals or humans).

Hazard identification of urban dust from various places has shown its hazardous nature. For example, Adamson et al. [78] showed that urban dust from Canada could cause pulmonary toxicity (inflammation and fibrosis) that could be attributed to metals in the soluble fraction. The metals included some heavy metals such as copper, iron, lead, tin, titanium, and zinc. Urban dust in such countries as Italy and South Africa has also been shown to be highly toxic to invertebrates (Sphaerechinus granularis and Caenorhabditis elegans) [79] and the BEAS-2B cell line [80]. In a comparative study [81], $\mathrm{Zn}$ and $\mathrm{Cu}$ in urban dust was shown to be most likely to cause lung injury and inflammation compared to similar concentrations of other metals such as $\mathrm{Ni}, \mathrm{Fe}, \mathrm{Pb}$, and $\mathrm{V}$. These studies show that 
the inherent hazardous nature of the dust depends on the composition and the inherent source of the dust.

The dose-response-assessment process aims to evaluate responses at particular exposure levels [82], where a response can be any "detectable adverse alteration of morphology, functional capacity, growth, development or life span of the target organism" [83]. In most cases, urban dust was shown to elicit effects in a dose-dependent manner. For example, O'Driscoll et al. [84] showed that ambient urban dust caused a route- and dose-dependent reduction of pathologic $T$ cells in the central nervous system. Similarly, urban dust has been shown to cause dose-dependent DNA damage [85].

Risk assessment of urban dust requires the assessment of exposure of various populations to urban dust in the exposure-assessment step. For inhalational risk, exposure can be assessed using actual external exposure based on ambient exposure levels or simulated internal exposure using lung deposition, bioaccessibility, and clearance of particles in the lungs. Indeed, Goix et al. [86] showed the importance of the use of the relevant size fractions, as well as the bioaccessibility of the heavy metals, in urban dust in risk assessment. In other words, knowledge of the total concentration of heavy metals in urban dust is not sufficient for the assessment of its risk.

Indeed, size fractions and particle size have been shown to be an important determinant of both toxicity of particles and risk. For example, Mirowsky et al. [87] showed that the aerodynamic size was among factors that affected the response of pulmonary endothelial cells to reactive oxygen species (ROS), as well as inflammation in mice. Size and size fractions are important for two reasons. First, there are higher concentrations of heavy metals in small particles than in larger fractions [88]. Han et al. [89] showed that with the exception of $\mathrm{Ba}$ and $\mathrm{Co}$, other metals such as $\mathrm{Cr}, \mathrm{Pb}$, and $\mathrm{Zn}$ were accumulated in the $<50 \mu \mathrm{m}$ particles. Hieu and Lee [90] also reported high concentrations of heavy metals $(\mathrm{Cd}, \mathrm{Cr}, \mathrm{Cu}, \mathrm{Ni}, \mathrm{Mn}$, and $\mathrm{Pb})$ in fine particles, with high concentrations of only two heavy metals (Fe and $\mathrm{Zn}$ ) in coarse particles. Similarly, use of size-selective particle sampling could reveal increasing heavy-metal concentrations with decreasing aerodynamic diameter for $\mathrm{V}, \mathrm{Mn}, \mathrm{Ni}, \mathrm{Cu}, \mathrm{Zn}$, and $\mathrm{Cd}$, while some heavy metals, including $\mathrm{Mo}, \mathrm{Fe}, \mathrm{Sb}, \mathrm{Sn}$, and $\mathrm{Pb}$, were largely concentrated in fine particles [91].

Second, smaller particles penetrate deeper into the lungs than larger particles $[92,93]$. As an example, Deng et al. [94] reported that coarse particles $(>2.5 \mu \mathrm{m})$ were mainly deposited in the tracheobronchial region, while fine particles $(<2.5 \mu \mathrm{m})$ were mainly deposited in the pulmonary region. For these, reasons, deposition modelling is required in the health-risk assessment of urban dust. Deposition models, such as the multipathway particle dosimetry model (MPPD), International Commission on Radiological Protection (ICRP) models, and the National Council on Radiation Protection and Measurement (NCRP) model, provide more accurate lung-dose estimations by incorporating specific physicochemical and biokinetic parameters that affect the dose of inhaled particles.

Using the MPPD model, Long et al. [95] estimated a non-carcinogenic risk (HI) of less than 1 from pulmonary-deposition fractions ranging from $12.4 \%$ to $15.1 \%$ and $6.66 \%$ to $12.3 \%$ for fine and coarse particles, respectively, for 17 elements. Megido et al. [93] also used the MPPD model to show that $40.2 \%$ of the particles were inhaled and deposited in the human respiratory tract, with $12.3 \%$ of the particles reaching the deepest zones.

Non-cancer risk can also be based on heavy-metal doses calculated using simple mathematical equations that are based on the United States Environmental Protection Agency (USEPA) methodology for risk assessment. For example, Equations (1) and (2) can be used to calculate the daily dose resulting from inhalation $\left(D_{i n h}\right)$, while Equations (3) and (4) can be used to estimate the ingestion $\left(D_{\text {ing }}\right)$ and dermal $\left(D_{\text {der }}\right)$ doses, respectively:

$$
\begin{gathered}
D_{i n h}=\frac{C_{p} \times I n h R \times P_{a} \times R F \times E T \times E F \times E D \times C F}{B W \times A T} \\
D_{i n h}=\frac{I n h R \times P_{a} \times R F \times E T \times E F \times E D \times C F}{P E F \times B W \times A T}
\end{gathered}
$$




$$
\begin{gathered}
D_{\text {ing }}=\frac{C_{p} \times \operatorname{Ing} R \times E F \times E D \times C F}{B W \times A T} \\
D_{\text {Der }}=\frac{C_{p} \times S_{L} \times S A \times A F \times A B S \times E F \times E D \times C F}{B W \times A T}
\end{gathered}
$$

where $C_{p}$ is the chemical concentration in airborne particles $(\mathrm{mg} / \mathrm{mg}), P_{a}$ is the particle concentration in air $\left(\mathrm{mg} / \mathrm{m}^{3}\right), R F$ is the respirable fraction of particulates (unitless), InhR is the inhalation rate $\left(\mathrm{m}^{3} /\right.$ day), $E T$ is the exposure time (h/day), $E D$ is the exposure duration (days), $B W$ is the body weight of the exposed group $(\mathrm{kg}), A B S$ is the absorption factor (unitless), $A F$ is the soil-adhesion factor (in $\mathrm{mg} / \mathrm{cm}^{2}$ ), and $A T$ is the averaging time (days) [96,97]. PEF is the particulate emission factor that relates the concentration of contaminant in soil with the concentration of dust particles in the air [98]. A default $P E F$ value of $1.36 \times 10^{9} \mathrm{~m}^{3} / \mathrm{kg}$ is commonly used. Equation (2) and $P E F$ are used when the concentration of the heavy metal in the atmosphere is not known, as required in Equation (1).

Non-cancer risks are estimated by comparing the dose with toxicological parameters such as the reference dose to calculate hazard quotients (HQs), hazard indices (HIs), and margin of safety (MOSs), or NOAELs to calculate the margin of exposures (MOEs). The risk of cancer from genotoxic carcinogens is estimated using Equation (5):

$$
\text { Risk }=L A D D \times C S F
$$

where risk is a unitless probability of an individual developing cancer, $L A D D$ is the lifetime average daily dose $(\mathrm{mg} / \mathrm{kg} / \mathrm{d})$, and CSF is the cancer slope factor expressed in $(\mathrm{mg} / \mathrm{kg} / \mathrm{d})^{-1}$.

$$
\operatorname{LADD}\left(\frac{m g}{k g \cdot d a y}\right)=C \times \frac{E F}{A T} \times\left(\text { ing } R_{\text {child }} \times \frac{E D_{\text {child }}}{B W_{\text {child }}}+i n g R_{\text {adult }} \times \frac{E D_{\text {adult }}}{B W_{\text {adult }}}\right) \times 10^{-6}
$$

Using PEF, LADD can also be estimated for the inhalation route using Equation (7):

$$
\operatorname{LADD}\left(\frac{m g}{k g \cdot d a y}\right)=C \times \frac{E F}{A T \times P E F} \times\left(I n h R_{\text {child }} \times \frac{E D_{\text {child }}}{B W_{\text {child }}}+\operatorname{Inh} R_{\text {adult }} \times \frac{E D_{\text {adult }}}{B W_{\text {adult }}}\right) \times 10^{-6}
$$

For the inhalation route, the exposure concentration $(E C)$ can be used directly, together with inhalational unit risks (IURs), to estimate the incremental cancer risks, as shown in Equation (8) [99]:

$$
\text { Risk }=I U R \times E C
$$

The IUR can be calculated from the CSFs and is expressed in units of $1 / \mu \mathrm{g} / \mathrm{m}^{3}$, while the EC has units of $\mu \mathrm{g} / \mathrm{m}^{3}$. The IURs, also known as unit-risk estimates [100], are used to estimate lifetime cancer risks associated with inhalation exposure to carcinogens [101].

These and similar equations have been used to estimate exposure and risks of exposure to heavy metals in urban dusts in many cities around the world. In some cases, there are no appreciable cancer and non-cancer risks, while there are significant risks in others. For example, Chonokhuu et al. [102] calculated acceptable non-cancer and cancer risks from urban dust in industrial cities of Mongolia. Similarly, non-significant cancer and non-cancer risks have been reported in other places, such as in Ahvaz, Iran [103] and Northwest China [104]. On the other hand, major cancer and/or non-cancer risks were reported in Baotou city in China [105], Tianjin in China [15,106] and the Persian Gulf [107].

In many risk-assessment reports, significant differences have been reported between risks for children and those for adults. For example, in Tianjin, China, total carcinogenic risk for children $\left(2.01 \times 10^{-3}\right)$ was almost twice that for adults $\left(1.05 \times 10^{-3}\right)$ [106]. The non-cancer risk for children (0.588) was also twice as large as that for adults (0.280). Similar differences have been reported elsewhere, including in Lanzhou, Northwest China [104], 
Jharia (India) [65], and the Persian Gulf [107]. These differences were attributed to higher metabolic rates, as well as differences in hand-to-mouth activities and time-activity patterns between adults and children [97].

Notable differences have also been reported between risks from outdoor and indoor urban dust [34]. These differences have largely been attributed to differences in composition of indoor and outdoor dust that result from differences in the sources that contribute to these types of dust. For example, in Southwest China, the non-cancer risks for $\mathrm{Zn}, \mathrm{Cr}, \mathrm{Mn}$, $\mathrm{Hg}$, and $\mathrm{Cu}$ were mainly attributed to indoor dust, which had higher levels of $\mathrm{Pb}, \mathrm{Cd}$, and As than did outdoor dust [34]. Potential sources of the pollutants in indoor dust were cited as animals, furniture, and other human activities such as smoking, cleaning, and coal combustion. Similarly, in Kuala Lumpur, Malaysia, the major source of heavy metals in indoor dust was road dust (69\%), whereas soil was the dominant source for outdoor dust $(74 \%)$ [108]. The differences in levels of heavy metals in urban dust are likely to be site-specific, and it is therefore important to account for these differences in the design of risk-assessment studies of heavy metals in urban dust.

In source-specific risk assessments, distance from the source is an important factor that determines the level of risk. For example, in China the concentration of $\mathrm{Pb}$ in urban dust decreased exponentially with increasing distance from lead industries [109,110]. Therefore, the level of risk in relation to distance from one source can be estimated using an exponential equation of distance from the source. In the presence of numerous sources, Yu et al. [109] showed that the use of Bayesian analysis could result in less uncertainty for estimating $\mathrm{Pb}$ dust than maximum likelihood estimation (MLE). These tools can be used in conjunction with spatial statistical tools, such as spatial interpolation and ordinary kriging, to prepare contour maps that allow more elaborate visual assessment of the distribution of heavy metals in urban areas [56].

The most recent studies on the health-risk assessment of heavy metals in atmospheric dust have been conducted in the Northern Hemisphere; i.e., Europe, North America, and Asia. In particular, there have been numerous studies in cities in China, with some notable differences and similarities among various cities, depending on the prevalent sources in the city. For example, in the eastern Chinese city of Huainan, street dust contained moderate to high levels of $\mathrm{Cd}$ and $\mathrm{Hg}$, primarily from motor vehicles, industries, weathering of coal dust, and natural soils, as well as coal combustion [111]. Similarly in Beijing, street dust contained high levels of $\mathrm{Cd}$ and $\mathrm{Hg}$, in addition to other metals, from motor vehicles, coal combustion, metal manufacturing and processing industries, as well as use of pesticides, fertilizers, and medical devices [112].

In northern Spain, elevated concentrations were reported for $\mathrm{Zn}, \mathrm{Cd}$, and $\mathrm{Hg}$ in dust samples from streets located near industrial areas. The most important sources were metallurgical processes, transportation of raw materials for local industries, and motorvehicle traffic [63]. In the Polish city of Lublin, levels were reported for heavy metals $(\mathrm{Zn}, \mathrm{Cd}, \mathrm{Cu}, \mathrm{Pb}, \mathrm{Ni}) . \mathrm{Cu}$ and $\mathrm{Zn}$ in road dust decreased between 2013 and 2018, and were assessed to not pose a significant risk to human health [113]. Overall, since 1990, the concentration and environmental risks of many heavy metals have declined in Europe, as shown by biomonitoring studies in mosses [114]. Nevertheless, hotspots still remain, such as Albania, where dominant sources include natural contamination and dust emissions from local mining operations and mineral dumps [115].

Few studies have been conducted recently in Africa on the health-risk assessment of heavy metals in urban atmospheric dust. In Ghana, both non-cancer and cancer risks for heavy metals in dust around fuel filling stations were reported to be below the threshold values [116]. These results were similar to the findings on environmental and human health risk of heavy metals in atmospheric $\mathrm{PM}_{10}$ around gas-flaring activities in Nigeria [117]. In South Africa, dust from inside and outside classrooms had elevated concentrations of $\mathrm{Zn}$, with significant differences in the concentrations of trace metals from the schools [64]. Positive correlation showed that elements such as $\mathrm{Pb}, \mathrm{Cu}, \mathrm{Zn}, \mathrm{Mn}$, and $\mathrm{Sb}$ possibly had one 
common source. In Egypt, widespread heavy-metal contamination was reported, especially $\mathrm{Pb}, \mathrm{Mn}$, and $\mathrm{Fe}$, in outdoor, indoor, and street dust [118].

In addition to the estimation of risks using HQs and incremental cancer risk, pollution indices are often used in the risk assessment of heavy metals in soil and dust. These indices help to assess the extent of contamination, as well as to determine if the source of contamination is due to natural processes or anthropogenic activities. These indices have been adequately and comprehensively discussed elsewhere, most notably by Kowalska et al. [119]. Generally, the determination of metals in urban dust is important, but it will be more significant if risk studies are added on top of mere analysis of toxicants.

\section{Conclusions}

As shown in this review, there have been many studies conducted on heavy metals in urban dust. These studies have shown that urban dust in close proximity to industrial or other anthropogenic activities tend to have higher heavy-metal concentrations than that sampled in other areas. The dust in areas of high anthropogenic activities such as mining poses a high risk to both humans and invertebrates. To compliment studies on metal levels in dust, it is always important to carry out risk assessments. These risk-assessment studies are important, as they have revealed which groups of individuals are more at risk than others, and which type of dust (indoor vs. outdoor) contains more contaminants than the other. Quantification of health risks according to sources, rather than individual pollutants, is important for risk mitigation and management, and it may reveal complex relationships between urban dust and adverse health.

Author Contributions: In this study, C.C.K. developed the author roles, title, abstract, methods of sampling and determination, conclusion, and references, and compiled the paper. I.B.M.K. developed the section on the levels of heavy metals in urban dust and proofread the paper. W.R.U. developed the introduction, source apportionment, and risk-assessment sections of the paper. All authors have read and agreed to the published version of the manuscript.

Funding: This study did not receive any funding.

Institutional Review Board Statement: Not applicable.

Informed Consent Statement: Not applicable.

Conflicts of Interest: The authors declare no conflict of interest.

\section{References}

1. Nakajima, F.; Aryal, R. Heavy metals in urban dust. In Heavy Metals; Saleh, H.E.M., Aglan, R.F., Eds.; IntechOpen Limited: London, UK, 2018; pp. 303-318.

2. Mitsakou, C.; Kallos, G.; Papantoniou, N.; Spyrou, C.; Solomos, S.; Astitha, M.; Housiadas, C. Saharan dust levels in Greece and received inhalation doses. Atmos. Chem. Phys. 2008, 8, 7181-7192. [CrossRef]

3. World Health Organization (WHO). Hazard Prevention and Control in the Work Environment: Airborne Dust. 1999. Available online: https://www.who.int/occupational_health/publications/en/oehairbornedust3.pdf (accessed on 1 July 2021).

4. Yadav, I.C.; Devi, N.L.; Singh, V.K.; Li, J.; Zhang, G. Spatial distribution, source analysis, and health risk assessment of heavy metals contamination in house dust and surface soil from four major cities of Nepal. Chemosphere 2019, 218, 1100-1113. [CrossRef]

5. Men, C.; Liu, R.; Wang, Q.; Guo, L.; Miao, Y.; Shen, Z. Uncertainty analysis in source apportionment of heavy metals in road dust based on positive matrix factorization model and geographic information system. Sci. Total Environ. 2019, 652, 27-39. [CrossRef] [PubMed]

6. Sager, M. Urban soils and road dust-Civilization effects and metal pollution-A review. Environments 2020, 7, 98. [CrossRef]

7. Li, X. Levels and spatial distribution of heavy metals in urban dust in China. Chin. J. Geochem. 2015, 34, 498-506. [CrossRef]

8. Yu, Y.; Ma, J.; Song, N.; Wang, X.; Wei, T.; Yang, Z.; Li, Y. Comparison of metal pollution and health risks of urban dust in Beijing in 2007 and 2012. Environ. Monit. Assess. 2016, 188, 1-11. [CrossRef] [PubMed]

9. Lee, B.K.; Hieu, N.T. Seasonal variation and sources of heavy metals in atmospheric aerosols in a residential area of Ulsan, Korea. Aerosol Air Qual. Res. 2011, 11, 679-688. [CrossRef]

10. Tang, Y.; Han, G. Seasonal variation and quality assessment of the major and trace elements of atmospheric dust in a typical karst city, Southwest China. Int. J. Environ. Res. Public Health 2019, 16, 325. [CrossRef] 
11. Quass, U.; John, A.C.; Kuhlbusch, T.A.J. Source apportionment of airborne dust in Germany: Methods and results. In Urban Air Quality in Europe; Springer: Berlin/Heidelberg, Germany, 2012; pp. 195-218.

12. Jahandari, A. Pollution status and human health risk assessments of selected heavy metals in urban dust of 16 cities in Iran. Environ. Sci. Pollut. Res. 2020, 27, 23094-23107. [CrossRef]

13. Keshavarzi, B.; Tazarvi, Z.; Rajabzadeh, M.A.; Najmeddin, A. Chemical speciation, human health risk assessment and pollution level of selected heavy metals in urban street dust of Shiraz, Iran. Atmos. Environ. 2015, 119, 1-10. [CrossRef]

14. Cheng, Z.; Chen, L.-J.; Li, H.-H.; Lin, J.-Q.; Yang, Z.-B.; Yang, Y.-X.; Xu, X.-X.; Xian, J.-R.; Shao, J.-R.; Zhu, X.-M. Characteristics and health risk assessment of heavy metals exposure via household dust from urban area in Chengdu, China. Sci. Total Environ. 2018, 619, 621-629. [CrossRef] [PubMed]

15. Hu, B.; Liu, B.; Zhou, J.; Guo, J.; Sun, Z.; Meng, W.; Guo, X.; Duan, J. Health risk assessment on heavy metals in urban street dust of Tianjin based on trapezoidal fuzzy numbers. Hum. Ecol. Risk Assess. 2016, 22, 678-692. [CrossRef]

16. Du, Y.; Gao, B.; Zhou, H.; Ju, X.; Hao, H.; Yin, S. Health risk assessment of heavy metals in road dusts in urban parks of Beijing, China. Procedia Environ. Sci. 2013, 18, 299-309. [CrossRef]

17. Sahakyan, L.; Maghakyan, N.; Belyaeva, O.; Tepanosyan, G.; Kafyan, M.; Saghatelyan, A. Heavy metals in urban dust: Contamination and health risk assessment: A case study from Gyumri, Armenia. Arab. J. Geosci. 2016, 9, 142. [CrossRef]

18. Shabanda, I.S.; Koki, I.B.; Low, K.H.; Zain, S.M.; Khor, S.M.; Bakar, N.K.A. Daily exposure to toxic metals through urban road dust from industrial, commercial, heavy traffic, and residential areas in Petaling Jaya, Malaysia: A health risk assessment. Environ. Sci. Pollut. Res. 2019, 26, 37193-37211. [CrossRef]

19. Karim, Z.; Qureshi, B.A. Health risk assessment of heavy metals in urban soil of Karachi, Pakistan. Hum. Ecol. Risk Assess. 2014, 20, 658-667. [CrossRef]

20. Wei, B.; Jiang, F.; Li, X.; Mu, S. Spatial distribution and contamination assessment of heavy metals in urban road dusts from Urumqi, NW China. Microchem. J. 2009, 93, 147-152. [CrossRef]

21. Aguilera, A.; Armendariz, C.; Quintana, P.; Garcia-Oliva, F.; Bautista, F. Influence of land use and road type on the elemental composition of urban dust in a Mexican metropolitan area. Pol. J. Environ. Stud. 2019, 28, 1535-1547. [CrossRef]

22. Praveena, S.M. Characterization and risk analysis of metals associated with urban dust in Rawang (Malaysia). Arch. Environ. Contam. Toxicol. 2019, 75, 415-423. [CrossRef]

23. Zhang, C.; Qiao, Q.; Appel, E.; Huang, B. Discriminating sources of anthropogenic heavy metals in urban street dusts using magnetic and chemical methods. J. Geochem. Explor. 2012, 119-120, 60-75. [CrossRef]

24. Soltani, N.; Keshavarzi, B.; Moore, F.; Tavakol, T.; Lahijanzadeh, A.R.; Jaafarzadeh, N.; Kermani, M. Ecological and human health hazards of heavy metals and polycyclic aromatic hydrocarbons (PAHs) in road dust of Isfahan metropolis, Iran. Sci. Total Environ. 2015, 505, 712-723. [CrossRef]

25. Reyes, B.A.; Bautista, F.; Goguitchaichvili, A.; Contreras, J.J.M.; Owen, P.Q.; Carvallo, C.; Battu, J. Rock-magnetic properties of topsoils and urban dust from Morelia (>800,000 inhabitants), Mexico: Implications for anthropogenic pollution monitoring in Mexico's medium size cities. Geofis. Int. 2013, 52, 121-133.

26. Saghatelyan, A.; Sahakyan, L.; Belyaeva, O.; Maghakyan, N. Studying atmospheric dust and heavy metals on urban sites through synchronous use of different methods. J. Atmos. Pollut. 2014, 2, 12-16.

27. Trujilo-Gonzalez, J.M.; Torres-Mora, M.A.; Keesstra, S.; Brevik, E.C.; Jimenez-Ballesta, R. Heavy metal accumulation related to population density in road dust samples taken from urban sites under different land uses. Sci. Total Environ. 2016, 553, 636-642. [CrossRef]

28. Tanner, P.; Lingma, H.; Yu, P.K.N. Fingerprinting metals in urban street dust of Beijing, Shanghai, and Hong Kong. Environ. Sci. Technol. 2008, 42, 7111-7117. [CrossRef] [PubMed]

29. Budai, P.; Clement, A. Spatial distribution patterns of four traffic-emitted heavy metals in urban road dust and the resuspension of brake-emitted particles: Findings of a field study. Transp. Res. D Transp. Environ. 2018, 62, 179-185. [CrossRef]

30. Lundberg, J.; Blomqvist, G.; Gustafsson, M.; Janhäll, S.; Järlskog, I. Wet dust sampler-A sampling method for road dust quantification and analyses. Water Air Soil Pollut. 2019, 230, 180. [CrossRef]

31. Colinet, J. Dust Sampling Instrumentation and Methods. 2010. Available online: https://www.cdc.gov/niosh/mining/userfiles/ workshops / silicamnm2010/3-colinet-dustsampling.pdf (accessed on 3 June 2021).

32. Sharma, B.; Tyagi, S. Simplification of metal ion analysis in fresh water samples by atomic absorption spectroscopy for laboratory students. J. Lab. Chem. Edu. 2013, 1, 54-58.

33. Shi, G.; Chen, Z.; Bi, C.; Wang, L.; Teng, J.; Li, Y.; Xu, S. A comparative study of health risk of potentially toxic metals in urban and suburban road dust in the most populated city of China. Atmos. Environ. 2011, 45, 764-771. [CrossRef]

34. Cao, S.; Chen, X.; Zhang, L.; Xing, X.; Wen, D.; Wang, B.; Qin, N.; Wei, F.; Duan, X. Quantificational exposure, sources, and health risks posed by heavy metals in indoor and outdoor household dust in a typical smelting area in China. Indoor Air 2020, 30, 872-884. [CrossRef]

35. Benhaddya, M.L.; Boukhelkhal, A.; Halis, Y.; Hadjel, M. Human health risks associated with metals from urban soil and road dust in an oilfield area of South eastern Algeria. Arch. Environ. Contam. Toxicol. 2016, 70, 556-571. [CrossRef]

36. Adamiec, E.; Jarosz-Krzeminska, E.; Wieszala, R. Heavy metals from non-exhaust vehicle emissions in urban and motorway road dusts. Environ. Monit. Assess. 2016, 188, 369. [CrossRef] 
37. Cortes, J.; Bautista, F.; Delgado, C.; Quintana, P.; Aguilar, D.; Garcia, L.; Figueroa, C.; Gogichaishvili, A. Spatial distribution of heavy metals in urban dust from Ensenada, Baja California, Mexico. Rev. Chapingo Ser. Cienc. For. Ambiente 2017, 23, 47-60. [CrossRef]

38. Davila, A.F.; Rey, D.; Mohamed, K.; Rubio, B.; Guerra, A.P. Mapping the sources of urban dust in a coastal environment by measuring magnetic parameters of Platanus hispanica leaves. Environ. Sci. Technol. 2006, 40, 3922-3928. [CrossRef] [PubMed]

39. Bioline Global Private Limited. 5 Key Points to Consider when Purchasing Lab. Equipment. 2021. Available online: https: / / www.biolineglobal.com.au/5-key-points-to-consider-when-purchasing-lab-equipment/ (accessed on 1 July 2021).

40. Brooks Applied Labs. Interference Removal by ICP-DRC-MS. 2021. Available online: https://brooksapplied.com/services/ interference-reduction-technology/spectral-interference-removal-icp-drc-ms/ (accessed on 2 June 2021).

41. Kawabata, K.; Kishi, Y.; Thomas, R. The benefits of dynamic reaction cell ICP-MS technology to determine ultratrace metal contamination levels in high-purity phosphoric and sulfuric acid. Spectroscopy 2003, 18, 16-31.

42. Wilschefski, S.C.; Baxter, M.R. Inductively coupled plasma mass spectrometry: Introduction to analytical aspects. Clin. Biochem. Rev. 2019, 40, 115-133. [CrossRef] [PubMed]

43. Mathias, J. The Advantages and Disadvantages of X-ray Photoelectron Spectroscopy (XPS/ESCA). 2019. Available online: https:/ / www.innovatechlabs.com/newsroom/2012/advantages-disadvantages-xps-testing-analysis/ (accessed on 7 June 2021).

44. Liu, J.; Liu, Y.J.; Liu, Y.; Liu, Z.; Zhang, A.N. Quantitative contributions of the major sources of heavy metals in soils to ecosystem and human health risks: A case study of Yulin, China. Ecotoxicol. Environ. Saf. 2018, 164, 261-269. [CrossRef]

45. Guo, G.; Zhang, D. Source apportionment and source-specific health risk assessment of heavy metals in size-fractionated road dust from a typical mining and smelting area, Gejiu, China. Environ. Sci. Pollut. Res. 2021, 28, 9313-9326. [CrossRef]

46. Sarnat, J.A.; Marmur, A.; Klein, M.; Kim, E.; Russell, A.G.; Sarnat, S.E.; Mulholland, J.A.; Hopke, P.K.; Tolbert, P.E. Fine particle sources and cardiorespiratory morbidity: An application of chemical mass balance and factor analytical source-apportionment methods. Environ. Health Perspect. 2008, 116, 459-466. [CrossRef] [PubMed]

47. Brines, M.; Dall'Osto, M.; Amato, F.; Minguillón, M.C.; Karanasiou, A.; Grimalt, J.O.; Alastuey, A.; Querol, X.; van Drooge, B.L. Source apportionment of urban PM 1 in Barcelona during SAPUSS using organic and inorganic components. Environ. Sci. Pollut. Res. 2019, 26, 32114-32127. [CrossRef]

48. Karagulian, F.; Belis, C.A. Enhancing source apportionment with receptor models to foster the air quality directive implementation. Int. J. Environ. Pollut. 2012, 50, 190-199. [CrossRef]

49. Hopke, P.K. Review of receptor modeling methods for source apportionment. J. Air Waste Manag. Assoc. 2016, 66, 237-259. [CrossRef] [PubMed]

50. Chen, P.; Wang, T.; Hu, X.; Xie, M. Chemical mass balance source apportionment of size-fractionated particulate matter in Nanjing, China. Aerosol Air Qual. Res. 2015, 15, 1855-1867. [CrossRef]

51. Mummullage, S.; Egodawatta, P.; Ayoko, G.A.; Goonetilleke, A. Use of physicochemical signatures to assess the sources of metals in urban road dust. Sci. Total Environ. 2016, 541, 1303-1309. [CrossRef] [PubMed]

52. Mihankhah, T.; Saeedi, M.; Karbassi, A. A comparative study of elemental pollution and health risk assessment in urban dust of different land-uses in Tehran's urban area. Chemosphere 2020, 241, 124984. [CrossRef]

53. Barbieri, M. The importance of enrichment factor (EF) and geoaccumulation index (Igeo) to evaluate the soil contamination. $J$. Geol. Geophys. 2016, 5, 1-4. [CrossRef]

54. Kłos, A.; Rajfur, M.; Wacławek, M. Application of enrichment factor (EF) to the interpretation of results from the biomonitoring studies. Ecol. Chem. Eng. S 2011, 18, 171-183.

55. Binaku, K.; Schmeling, M. Multivariate statistical analyses of air pollutants and meteorology in Chicago during summers 2010-2012. Air Qual. Atmos. Health 2017, 10, 1227-1236. [CrossRef]

56. Núñez-Alonso, D.; Pérez-Arribas, L.V.; Manzoor, S.; Cáceres, J.O. Statistical tools for air pollution assessment: Multivariate and spatial analysis studies in the Madrid region. J. Anal. Methods Chem. 2019, 2019, 1-10. [CrossRef]

57. Das, A.; Kumar, R.; Patel, S.S.; Saha, M.C.; Guha, D. Source apportionment of potentially toxic elements in street dust of a coal mining area in Chhattisgarh, India, using multivariate and lead isotopic ratio analysis. Environ. Monit. Assess. 2020, 192, 1-14. [CrossRef]

58. Wang, P.; Li, Z.; Liu, J.; Bi, X.; Ning, Y.; Yang, S.; Yang, X. Apportionment of sources of heavy metals to agricultural soils us-ing isotope fingerprints and multivariate statistical analyses. Environ. Pollut. 2019, 249, 208-216. [CrossRef]

59. Huang, Q.; Chen, J.; Huang, W.; Fu, P.; Guinot, B.; Feng, X.; Shang, L.; Wang, Z.; Wang, Z.; Yuan, S.; et al. Isotopic composition for source identification of mercury in atmospheric fine particles. Atmos. Chem. Phys. 2016, 16, 11773-11786. [CrossRef]

60. Fekiacova, Z.; Cornu, S.; Pichat, S. Tracing contamination sources in soils with Cu and Zn isotopic ratios. Sci. Total Environ. 2015, 517, 96-105. [CrossRef]

61. Zhao, L.; Hua, G.; Yan, Y.; Yu, R.; Cui, J.; Wang, X.; Yan, Y. Source apportionment of heavy metals in urban road dust in a continental city of eastern China: Using $\mathrm{Pb}$ and $\mathrm{Sr}$ isotopes combined with multivariate statistical analysis. Atmos. Environ. 2019, 201, 201-211. [CrossRef]

62. Ferreira-Baptista, L.; De Miguel, E. Geochemistry and risk assessment of street dust in Luanda, Angola: A tropical urban environment. Atmos. Environ. 2005, 39, 4501-4512. [CrossRef]

63. Ordonez, A.; Loredo, J.; De Miguel, E.; Charlesworth, S. Distribution of heavy metals in the street dusts and soils of an in-dustrial city in Northern Spain. Arch. Environ. Contam. Toxicol. 2003, 44, 160-170. [CrossRef] 
64. Olowoyo, J.O.; Mugivhisa, L.L.; Magoloi, Z.G. Composition of trace metals in dust samples collected from selected high schools in Pretoria, South Africa. Appl. Environ. Soil Sci. 2016, 2016, 1-9. [CrossRef]

65. Rout, T.K.; Masto, R.; Ram, L.; George, J.; Padhy, P.K. Assessment of human health risks from heavy metals in outdoor dust samples in a coal mining area. Environ. Geochem. Health 2013, 35, 347-356. [CrossRef]

66. Elom, N.I.; Entwistle, J.; Dean, J.R. Human health risk from $\mathrm{Pb}$ in urban street dust in northern UK cities. Environ. Chem. Lett. 2014, 12, 209-218. [CrossRef]

67. Dytłow, S.; Górka-Kostrubiec, B. Concentration of heavy metals in street dust: An implication of using different geochemical background data in estimating the level of heavy metal pollution. Environ. Geochem. Health 2021, 43, 521-535. [CrossRef] [PubMed]

68. Middleton, N.; Kang, U. Sand and dust storms: Impact mitigation. Sustainability 2017, 9, 1053. [CrossRef]

69. Hamidi, M.; Kavianpour, M.R.; Shao, Y. Synoptic analysis of dust storms in the Middle East. Asia-Pac. J. Atmos. Sci. 2013, 49, 279-286. [CrossRef]

70. Zhu, Z.; Sun, G.; Bi, X.; Li, Z.; Yu, G. Identification of trace metal pollution in urban dust from kindergartens using magnetic, geochemical and lead isotopic analyses. Atmos. Environ. 2013, 77, 9-15. [CrossRef]

71. Abbasi, S.; Keshavarzi, B.; Moore, F.; Delshab, H.; Soltani, N.; Sorooshian, A. Investigation of microrubbers, microplastics and heavy metals in street dust: A study in Bushehr city, Iran. Environ. Earth Sci. 2017, 76, 1-19. [CrossRef]

72. Liu, E.; Yan, T.; Birch, G.; Zhu, Y. Pollution and health risk of potentially toxic metals in urban road dust in Nanjing, a mega-city of China. Sci. Total Environ. 2014, 476, 522-531. [CrossRef] [PubMed]

73. Tang, R.; Ma, K.; Zhang, Y.; Mao, Q. The spatial characteristics and pollution levels of metals in urban street dust of Beijing, China. Appl. Geochem. 2013, 35, 88-98. [CrossRef]

74. Rajaram, B.S.; Suryawanshi, P.V.; Bhanarkar, A.D.; Rao, C.V.C. Heavy metals contamination in road dust in Delhi city, India Environ. Earth Sci. 2014, 72, 3929-3938. [CrossRef]

75. Amato, F.; Pandolfi, M.; Moreno, T.; Furger, M.; Pey, J.; Alastuey, A.; Querol, X. Sources and variability of inhalable road dust particles in three European cities. Atmos. Environ. 2011, 45, 6777-6787. [CrossRef]

76. Tume, P.; Bech, J.; Sepulveda, B.; Tume, L.; Bech, J. Concentrations of heavy metals in urban soils of Talcahuano (Chile): A preliminary study. Environ. Monit. Assess. 2008, 140, 91-98. [CrossRef] [PubMed]

77. Benin, A.L.; Sargent, J.D.; Dalton, M.; Roda, S. High concentrations of heavy metals in neighborhoods near ore smelters in northern Mexico. Environ. Health Perspect. 1999, 107, 279-284. [CrossRef] [PubMed]

78. Adamson, I.Y.; Prieditis, H.; Vincent, R. Pulmonary toxicity of an atmospheric particulate sample is due to the soluble fraction. Toxicol. Appl. Pharmacol. 1999, 157, 43-50. [CrossRef]

79. Trifuoggi, M.; Pagano, G.; Oral, R.; Gravina, M.; Toscanesi, M.; Mozzillo, M.; Siciliano, A.; Burić, P.; Lyons, D.M.; Palumbo, A. Topsoil and urban dust pollution and toxicity in Taranto (southern Italy) industrial area and in a residential district. Environ. Monit. Assess. 2019, 191, 43. [CrossRef] [PubMed]

80. Andraos, C.; Gulumian, M. The toxicity of respirable South African mine tailings dust in relation to their physicochemical properties. Inhal. Toxicol. 2020, 32, 431-445. [CrossRef] [PubMed]

81. Prieditis, H.; Adamson, I. Comparative pulmonary toxicity of various soluble metals found in urban particulate dusts. Exp. Lung Res. 2002, 28, 563-576. [CrossRef]

82. USEPA. Guidelines for Carcinogen Risk Assessment. 2005. Available online: https://www.epa.gov/risk/guidelines-carcinogenrisk-assessment (accessed on 19 April 2021).

83. Nielsen, E.; Ostergaard, G.; Larsen, J.C. Toxicological Risk Assessment of Chemicals: A Practical Guide; CRC Press: Boca Raton, FL, USA, 2008.

84. O'driscoll, C.A.; Owens, L.A.; Hoffmann, E.J.; Gallo, M.E.; Afrazi, A.; Han, M.; Fechner, J.H.; Schauer, J.J.; Bradfield, C.A.; Mezrich, J.D. Ambient urban dust particulate matter reduces pathologic T cells in the CNS and severity of EAE. Environ. Res. 2019, 168, 178-192. [CrossRef]

85. Danielsen, P.H.; Loft, S.; Møller, P. DNA damage and cytotoxicity in type II lung epithelial (A549) cell cultures after exposure to diesel exhaust and urban street particles. Part. Fibre Toxicol. 2008, 5, 1-12. [CrossRef]

86. Goix, S.; Uzu, G.; Oliva, P.; Barraza, F.; Calas, A.; Castet, S.; Point, D.; Masbou, J.; Duprey, J.L.; Huayta, C. Metal concentration and bioaccessibility in different particle sizes of dust and aerosols to refine metal exposure assessment. J. Hazard. Mater. 2016, 317, 552-562. [CrossRef]

87. Mirowsky, J.; Hickey, C.; Horton, L.; Blaustein, M.; Galdanes, K.; Peltier, R.E.; Chillrud, S.; Chen, L.C.; Ross, J.; Nadas, A.; et al. The effect of particle size, location and season on the toxicity of urban and rural particulate matter. Inhal. Toxicol. 2013, 25, 747-757. [CrossRef]

88. Mun'im Mohd Han, N.; Latif, M.T.; Othman, M.; Dominick, D.; Mohamad, N.; Juahir, H.; Tahir, N.M. Composition of selected heavy metals in road dust from Kuala Lumpur city centre. Environ. Earth Sci. 2014, 72, 849-859.

89. Han, X.; Lu, X.; Zhang, Q.; Hai, Q.; Pan, H. Grain-size distribution and contamination characteristics of heavy metal in street dust of Baotou, China. Environ. Earth Sci. 2016, 75, 468. [CrossRef]

90. Hieu, N.T.; Lee, B.-K. Characteristics of particulate matter and metals in the ambient air from a residential area in the largest industrial city in Korea. Atmos. Res. 2020, 98, 526-537. [CrossRef] 
91. Niu, J.; Rasmussen, P.E.; Hassan, N.M.; Vincent, R. Concentration distribution and bioaccessibility of trace elements in nano and fine urban airborne particulate matter: Influence of particle size. Water Air Soil Pollut. 2010, 213, 211-225. [CrossRef]

92. Hammer, T.; Gao, H.; Pan, Z.; Wang, J. Relationship between aerosols exposure and lung deposition dose. Aerosol Air Qual Res. 2020, 20, 1083-1093. [CrossRef]

93. Megido, L.; Suárez-Peña, B.; Negral, L.; Castrillón, L.; Suárez, S.; Fernández-Nava, Y.; Marañón, E. Relationship between physico-chemical characteristics and potential toxicity of PM10. Chemosphere 2016, 162, 73-79. [CrossRef]

94. Deng, Q.; Deng, L.; Miao, Y.; Guo, X.; Li, Y. Particle deposition in the human lung: Health implications of particulate matter from different sources. Environ. Res. 2019, 169, 237-245. [CrossRef]

95. Long, L.; He, J.; Yang, X. Characteristics, emission sources and health risk assessment of trace elements in size-segregated aerosols during haze and non-haze periods at Ningbo, China. Environ. Geochem. Health 2021, 1-19. [CrossRef]

96. Liu, D. Review of mathematical models for health risk assessment: VII. chemical dose. Environ. Softw. 1994, 9, 153-160. [CrossRef]

97. Gabarrón, M.; Faz, A.; Acosta, J. Soil or dust for health risk assessment studies in urban environment. Arch. Environ. Contam. Toxicol. 2017, 73, 442-455. [CrossRef]

98. İpek, M.; Ünlü, K. Development of human health risk-based soil quality standards for Turkey: Conceptual framework. Environ. Adv. 2020, 1, 100004. [CrossRef]

99. USEPA. Risk Assessment Guidance for Superfund Volume I: Human Health Evaluation Manual (Part. F, Supplemental Guidance for Inhalation Risk Assessment). 2009. Available online: https:/ /www.epa.gov/risk/risk-assessment-guidance-superfund-ragspart-f (accessed on 15 April 2021).

100. Rice, F.; Park, R.; Stayner, L.; Smith, R.; Gilbert, S.; Checkoway, H. Crystalline silica exposure and lung cancer mortality in diatomaceous earth industry workers: A quantitative risk assessment. Occup. Environ. Med. 2001, 58, 38-45. [CrossRef]

101. OEHHA. Cobalt and Cobalt Compounds Cancer Inhalation Unit Risk Factors. 2020. Available online: https://oehha.ca.gov/ media/downloads/crnr/cobaltcpf100220.pdf (accessed on 20 April 2021).

102. Chonokhuu, S.; Batbold, C.; Chuluunpurev, B.; Battsengel, E.; Dorjsuren, B.; Byambaa, B. Contamination and health risk assessment of heavy metals in the soil of major cities in mongolia. Int. J. Environ. Res. Public Health 2019, 16, 2552. [CrossRef]

103. Ghanavati, N.; Nazarpour, A.; De Vivo, B. Ecological and human health risk assessment of toxic metals in street dusts and surface soils in Ahvaz, Iran. Environ. Geochem. Health 2019, 41, 875-891. [CrossRef] [PubMed]

104. Jiang, Y.; Shi, L.; Guang, A.-L.; Mu, Z.; Zhan, H.; Wu, Y. Contamination levels and human health risk assessment of toxic heavy metals in street dust in an industrial city in Northwest China. Environ. Geochem. Health 2018, 40, 2007-2020. [CrossRef]

105. Han, X.; Lu, X.; Wu, Y. Health risks and contamination levels of heavy metals in dusts from parks and squares of an industrial city in semi-arid area of China. Int. J. Environ. Res. Public Health 2017, 14, 886. [CrossRef]

106. Yu, B.; Wang, Y.; Zhou, Q. Human health risk assessment based on toxicity characteristic leaching procedure and simple bioaccessibility extraction test of toxic metals in urban street dust of Tianjin, China. PLoS ONE 2014, 9, e92459. [CrossRef] [PubMed]

107. Ghasemi, F.F.; Dobaradaran, S.; Saeedi, R.; Nabipour, I.; Nazmara, S.; Abadi, D.R.V.; Arfaeinia, H.; Ramavandi, B.; Spitz, J.; Mohammadi, M.J. Levels and ecological and health risk assessment of PM 2.5-bound heavy metals in the northern part of the Persian Gulf. Environ. Sci. Pollut. Res. 2020, 27, 5305-5313. [CrossRef] [PubMed]

108. Othman, M.; Latif, M.T.; Matsumi, Y. The exposure of children to PM2. 5 and dust in indoor and outdoor school classrooms in Kuala Lumpur City Centre. Ecotoxicol. Environ. Saf. 2019, 170, 739-749. [CrossRef]

109. Yu, Y.; Li, Y.; Li, B.; Shen, Z.; Stenstrom, M.K. Profiles of lead in urban dust and the effect of the distance to multi-industry in an old heavy industry city in China. Ecotoxicol. Environ. Saf. 2017, 137, 281-287. [CrossRef]

110. Wang, J.; Ren, H.; Zhang, X. Distribution patterns of lead in urban soil and dust in Shenyang city, Northeast China. Environ. Geochem. Health 2006, 28, 53-59. [CrossRef]

111. Tang, Z.; Chai, M.; Cheng, J.; Jin, J.; Yang, Y.; Nie, Z.; Huang, Q.; Li, Y. Contamination and health risks of heavy metals in street dust from a coal-mining city in eastern China. Ecotoxicol. Environ. Saf. 2017, 138, 83-91. [CrossRef]

112. Men, C.; Liu, R.; Wang, Q.; Guo, L.; Shen, Z. The impact of seasonal varied human activity on characteristics and sources of heavy metals in metropolitan road dusts. Sci. Total Environ. 2018, 637, 844-854. [CrossRef] [PubMed]

113. Zgłobicki, W.; Telecka, M.; Skupiński, S. Assessment of short-term changes in street dust pollution with heavy metals in Lu-blin (E Poland)—Levels, sources and risks. Environ. Sci. Pollut. Res. 2019, 26, 35049-35060. [CrossRef]

114. Harmens, H.; Norris, D.A.; Sharps, K.; Mills, G.; Alber, R.; Aleksiayenak, Y.; Blum, O.; Cucu-Man, S.M.; Dam, M.; De Temmerman, L.; et al. Heavy metal and nitrogen concentrations in mosses are declining across Europe whilst some "hotspots" remain in 2010. Environ. Pollut. 2015, 200, 93-104. [CrossRef] [PubMed]

115. Lazo, P.; Steinnes, E.; Qarri, F.; Allajbeu, S.; Kane, S.; Stafilov, T.; Frontasyeva, M.V.; Harmens, H. Origin and spatial distribu-tion of metals in moss samples in Albania: A hotspot of heavy metal contamination in Europe. Chemosphere 2018, 190, 337-349. [CrossRef]

116. Nkansah, M.A.; Darko, G.; Dodd, M.; Opoku, F.; Essuman, T.B.; Antwi-Boasiako, J. Assessment of pollution levels, potential ecological risk and human health risk of heavy metals/metalloids in dust around fuel filling stations from the Kumasi Metropolis, Ghana. Cogent Environ. Sci. 2017, 3, 1-19. [CrossRef]

117. Uzoekwe, S.A.; Izah, S.C.; Aigberua, A.O. Environmental and human health risk of heavy metals in atmospheric particulate matter (PM 10) around gas flaring vicinity in Bayelsa State, Nigeria. Toxicol. Environ. Health Sci. 2021, 1-13. [CrossRef] 
118. Rashed, M.N. Total and extractable heavy metals in indoor, outdoor and street dust from Aswan City, Egypt. Clean Soil Air Water 2008, 36, 850-857. [CrossRef]

119. Kowalska, J.B.; Mazurek, R.; Gąsiorek, M.; Zaleski, T. Pollution indices as useful tools for the comprehensive evaluation of the degree of soil contamination-A review. Environ. Geochem. Health 2018, 40, 2395-2420. [CrossRef] 